\title{
労働災害としての潜水病について
}

九州労災病院

鳥巣岳彦・川嶋真人

林皓・赤津隆

\section{Diver's disease}

\section{By}

\author{
T. Torisu, M. Kawashima, \\ K. Hayashi, \& T. Akatsu \\ Research Institute of Hyperbaric Medicine \\ Kyushu Rosai Hospital
}

\begin{abstract}
155 patients of diver's disease has been admitted to our hospital since the construction of hyperbaric chamber in 1966.

Among them, 30 patients had spinal cord lesions. 7 of them had complete transverse injuries, others were incomplete or dissociated type. Prognosis of our patients was good especially when recompression therapy had been undertaken in 6 hours after the onset of symtoms.
\end{abstract}

Etiology was discussed here.

潜水夫の人数は，その実態をつかむととが難しい が，全国でおおよそ 2 万人と推定される. 不虑の事故 が直ちに生命の危険につながる潜水活動は, 一触即発 の危機にたえず晒されているといえる.

九州労災病院高圧医療研究部に, 全国より昼夜の別 無くヘリコプターで搬送されて来る潜水病重症患者は 後をたたない現状にある. 昭和 41 年の大型高圧治療 タンク設置以来の潜水病入院患者は実に 155 名に達し ている.

労衝炎害として潜水事故を考える際には, 真の意味 の潜水病 (減圧症) の他に, 潜水時送気用ホースの破 損によるへルメット内外の圧の不均衡より生ずるスク イーズや，浮上時の肺破裂に伴なう呼吸困難等もその 中に含めて考えるべきではあるが，今回は真の意味の
潜水病（減圧症）について述べる.

潜水病は急性と慢性とに分けることが出来る．慢性 の潜水病とは長年の潜水で, 知らず知らずの内に起っ て来るあので, 骨関節の変化がそれである.乙れに関 しては別の演者が詳しく述べるので, こてでは急性の 潜水病, 中であ整形外科之関連の深い背䯣型について 述べてない.

まず潜水病で当院に入院した 155 名について, 林の 分類に従がい, 脳型, メニェール型, 背䯣型, チョー ク, ベンズの 5 型に分けてみると表 1 の通りになる. 脊髄型はベンズに次いで多発している事がわかる.

ての脊兪道型潜水病に関しては, 今日まで意外に等閑 視されていたのである. 事実, 日本パラプレジア学会 でむ, この種の脊髄障害は本年まで演題として提出さ

表 1 潜 水病 の 病 型

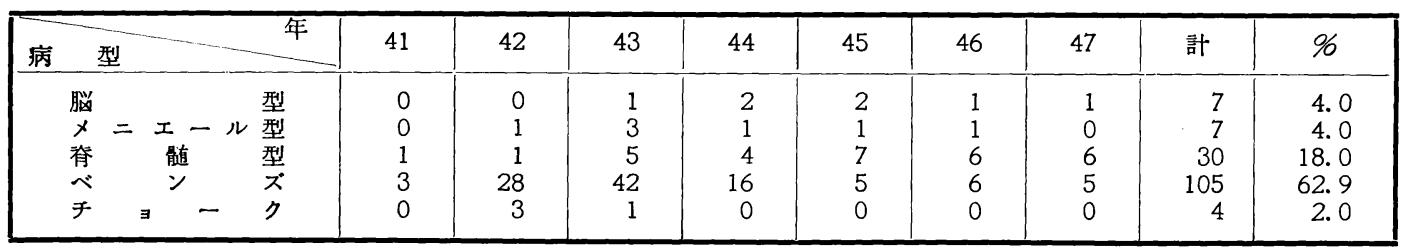


れることが無かったのである。一般に労働災害に於け る脊髄障害といえば, 外傷による脊䯣損傷を直ちに思 い浮べる程, その発生頻度からいっても外傷によるも のが大多数であることは事実である. しかし外傷性脊 骨道損傷に比へ，その発生頻度がはるかに少ないとはい え30名もの潜水夫に脊骾障害が発生している事実は,

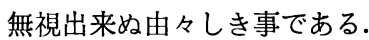

脊䯣型潜水病の症状を, 記載の 明確なむの 25 名に ついて見てみると, 対麻疸, 膀胱直腸障害, 知覚障害 の 3 つの症状がそろったものはわずかに 7 例である.

又 25 例中 21 例には知覚障害を認めたが 4 例は全く知 覚は正常であり, その麻疸の状態は表 3 の通りであ る.

知覚障害の認められた 21 例について脊䯣障害部位 を知覚正常域下限で示してみると表 2 の通りであり, 第 9 胸骾が最む多く，42.9\%をしめ，次に第 2,3 預䯣，次いで第 5,6 胸䯣の順になっている.

表 2 知党障害の位置 (正常域下限) 21 例

\begin{tabular}{|c|c|c|c|}
\hline 位置 & 例 & 数 & $\%$ \\
\hline $\begin{array}{l}\mathrm{C}_{2-3} \\
\mathrm{D}_{1-2} \\
\mathrm{D}_{5-6} \\
\mathrm{D}_{6-7} \\
\mathrm{D}_{8} \\
\mathrm{D}_{9} \\
\mathrm{D}_{12-} \mathrm{L}_{1}\end{array}$ & & & $\begin{array}{c}23.8 \\
5 \\
14.8 \\
5 \\
5 \\
42.9 \\
5\end{array}$ \\
\hline
\end{tabular}

表 3 知覚障害を認め姼例について

\begin{tabular}{|c|c|c|c|}
\hline $\begin{array}{l}\text { 知覚 障 害 } \\
\text { 害下運動障害 } \\
\text { 膀胱直腸 障 害 }\end{array}$ & + & $\underline{+}$ & $\overline{-}$ \\
\hline 例 & 2 & 1 & 1 \\
\hline
\end{tabular}

ここで潜水病としての脊䯣型と外傷性脊髄損傷とを 比較すると，脊䯣型潜水病には次の特徵がある.

1. 重度障害の場合は, 脊髄性ショック期では外傷 性脊髄障害と酷似するが, その後の回復経過にはかな りの差がみられ, 回復が早い.

2. 障害の程度は不全型や解離型が多い。

3. 障害の部位に好発部位があり，てれを知覚正常

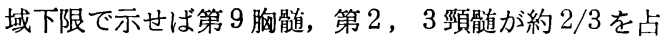
める.

4. 早期に再圧治療を行なえば予後は良好で, 特に 発症 6 時間以内であればほとんど完治可能である.

以上災害発生後直ちに適切な処置を施せば麻㾝を残
すととなく治癒させることが出来るのである.

その治療之は再圧タンクの中で再加圧を行ない, 気 泡化した窒素ガスを再溶解させ，乙れを今度は徐々に 肺より排出しなおすことである. 可及的早期に充分な 圧力で充分な時間をかけて再圧治療を行なえば完治も 可能である. 浮上後麻㾝が起った時, 直ちに深海に潜 りなおして，海底でシビレのとれるのを待つという， 潜水夫仲間で所謂 “ふかし”之称されている治療法 は，非科学的であり予後を悪くし，極めて危険である といえる.

最後に病因について述べてみたい，海底と言う高压 環境下で人体に高濃度に溶解した吸気中の窒素は, 浮 上に従がい肺から排出される由であるが，浮上速度が はや過ぎると肺からの排出が間に合わず，人体組織内 で直接気泡化してしまい，乙れが関節や筋肉の痛み， 呼吸困難, 下半身麻瘪などの種々の障害を引起して来

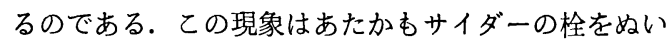
た時気泡が生ずるのに似ている．乙の気泡説は 1662 年 Robert Boyle が実験動物の血液中に 気泡を証明 して以来，今なお信じられている説である. しかして の気泡説は急性の減圧症を説明するのには適している が, 慢性の減圧症特に骨関節病変の発生を説明するに は少し難点がある.

一方 1950 年頃より脂肪栓塞説が この減圧症の分野 にあ登場して来たのである．窒素ガスは水より脂肪に 5 倍屯多く溶け込むわけで，一度急激な減圧が起れば この大量に溶解している脂肪中の窒素は気泡化してし まうのである. この事は先に述べたサイダーの栓をぬ いた時の気泡出現の状態と同じであるが，乙の気泡が 脂肪組織に器質的損僨を与え, その結果脂肪が血管の 栓塞を起すというのである．乙れは急性に起る外傷性 脂肪栓塞の症状と減圧症の症状とが類似しているとと や, 減圧症死亡例の肺に脂肪栓塞を認めること, 動物 実験で動物に減圧症を起させ，再圧治療をすることな く, ヘパリン等の外傷性脂肪栓塞治療剂の投与だけで 症状の改善をみたという報告などで最近有力となって 来た説である.

広大な海底資源を求めての海洋開発のため，あるい はスポーツやレクレーションのため, 潜水夫の数は増 加の傾向にある．潜水活動とはこれすべて減圧との戦 である．現在規定通りの減圧方法で浮上すれば急性の 減圧症は皆無に出来る。しかし慢性の減圧症即与骨関 節の変化は防ぎ得ないとされている. 我々は九州労災 
病院に於て患者を治療し，あるいは潜水夫の集団検診 を行なうことにより，現状を分析し，乙の分野の発展 のため微力を尽している現状にある.

\section{参考 献}

1）重藤 修・白石正士・長峯護 - 大町哲也・千蔵 収：高気圧圧障害（潜水病, 潜函病）の臨床と治 療(第 2 報), 症状固定の減圧症に対する治療法に ついて, 日災医会誌。第11巻第 1 号, 15-20, 嚾 和38年 1 月。

2）スタンリー・マイルズ著, 町田喜久雄訳: 潜水 医学入門(1971), 東京大学出版会.

3) Pualey, S. M. et al: Role of liprds in decompression sickness, Aerospae Med. Vol. 41 : 56-60, J. 1970.

4) Golding, F. C. et al : Decompression sickness during construction of the Dartford Tunnell. Briti. J. Industr. Med. Vol. $17: 167$ $-180,1960$.

5) McCallum, R. I. et al : Bone lesion in compressed air workers. J. B. J. S. 48-B : 207235, 1966.

6) Rivera, J. C. : Decompression sickness among divers, An analysis of 935 cases.
Military med. 314-334. 1964.

問山口大学整形 服部 奖

(1)脊髄型の好発障害部位之脊骾の解剖学的血行路と の関係について

(2)脊髄障害の治療成績について以上についてお尋ね します.

解 答 九州労災 鳥巣 岳彦

(1)脊髄型潜水病の好発部位は脊髄の血行と関係があ ると思われます.

(2)再圧治療をするまでの時間, 潜水夫がふかしをや ったかどうか, などにもまず関係しますが, 発症後 6 時間以内に再圧治療を開始すれば回復は良好でありま す.

\section{発 言 九州労災病院 天児 民和}

潜水は職業のみではなく, レヂャーとしても行なわ れるので，警戒しなければならない，特に $10 \mathrm{~m}$ 以上 深海に入るのは素人には危険である.

\section{減圧症で入院した潜水士の骨病変について}

九州労災病院

$\begin{array}{lllllll}\text { 整形外科川島真 人・鳥 巣 岳 彦 } \\ \text { 高压医療研究部 林 } & & \text { 晧 - 重 } & \text { 藤 } & \text { 脩 }\end{array}$

\section{Bone lesions in divers who were treated in Kyushu Rosai Hospital}

By

\section{Kawashima \& T. Torisu}

Kyushu Rosai Hospital

The department of Orthopedics

K. Hayashi \& O. Shigeto

The reserch institute of hyperbaric medicine

The first report of a suited diver with bone necrosis was made by Grutzmacher in 1941. Since 1966, when our hyperbaric chamber was constructed 155 divers were treated and 135 divers were examined radiologically. Of the 135,72 had aseptic bone necrosis.

We clasified these bone lesions according to Ota-Matsunaga's criteria. The juxta arti- 